УДК 541.1:541.18

\title{
КЛЮЧОВІ ПИТАННЯ ВИКЛАДАННЯ ЗМІСТОВОГО МОДУЛЯ “ФІЗИКО-ХІМІЯ ПОВЕРХНЕВИХ ЯВИЩ” У КУРСІ ФІЗИЧНОЇ ТА КОЛОЇДНОЇ ХІМІЇ В НАЦІОНАЛЬНОМУ ФАРМАЦЕВТИЧНОМУ УНIВЕРСИТЕТI
}

Л. Д. Грицан

Національний фармацевтичний університет

\section{KEY ISSUES OF TEACHING THE TOPICAL MODULE "PHYSICO- CHEMISTRY OF SURFACE PHENOMENA" IN THE COURSE OF PHYSICAL AND COLLOID CHEMISTRY AT THE NATIONAL UNIVERSITY OF PHARMACY}

L. D. Grytsan

\author{
National University of Pharmacy
}

\begin{abstract}
У представленій публікації висвітлено методичні підходи до викладання змістового модуля “Фізико-хімія поверхневих явищ” у курсі фізичної та колоїдної хімії студентам, які навчаються за напрямами “Фармація” та "Біотехнологія”, 3 урахуванням вимог кредитно-модульної системи. Підкреслено значення профілізації для стимулювання процесу набуття знань, умінь та практичних навичок майбутніми фахівцями.
\end{abstract}

The article adduces the methodological approaches to teaching the topical module "Physicochemistry of Surface Phenomena" in the course of Physical and Colloid Chemistry to students specializing in Pharmacy and Biotechnology taking into account the requirements of credit-transfer system. The importance of professional direction for stimulation of the process of acquiring knowledge and practical skills by future specialists is emphasized.

Вступ. Фізична та колоїдна хімія як фундаментальна дисципліна посідає важливе місце в системі вищої фармацевтичної освіти. Курс фізичної та колоїдної хімії завершує хімічну підготовку студентів, грунтується на знаннях, одержаних при вивченні інших фундаментальних дисциплін, та інтегрується 3 ними. Метою викладання фізичної та колоїдної хімії є забезпечення майбутнього фахівця фармацевтичної галузі такими спеціальними знаннями, уміннями i практичними навичками, які дадуть йому можливість повноцінно та якісно виконувати свої професійні обов'язки. Організація навчального процесу здійснюється за кредитно-модульною системою відповідно до вимог Болонської декларації, згідно з діючими програмами [1-5]. Курс фізичної та колоїдної хімії поділено на два модулі: “Фізична хімія” та “Колоїдна хімія: фізико-хімія поверхневих явищ та дисперсних систем". До складу другого модуля входить змістовий модуль “Фізико-хімія поверхневих явищ”, вивчення якого дозволяє сформувати освітнє підгрунтя для подальшого успішного опанування студентами спеціальних дисциплін, а саме технології ліків, фарма- цевтичної, біологічної та токсикологічної хімії, фармакогнозії, фармакології тощо.

Залежно від спеціальності та форми навчання студентів на викладання даного змістового модуля відводиться від двох до шести лекційних годин та від чотирьох до 12 годин лабораторних занять. Така невелика кількість аудиторних годин вимагає від викладача дуже ретельного підходу до відбору навчального матеріалу та методики його представлення.

Основна частина. Дана робота має на меті узагальнення та систематизацію багаторічного досвіду викладання основ фізико-хімії поверхневих явищ студентам Національного фармацевтичного університету.

Хоча поверхневі процеси і перебігають на будь-якій межі поділу фаз, але особливу роль вони відіграють у дисперсних системах. Як відомо, дисперсними називають гетерогенні дво- і багатофазні системи, в яких принаймні одна з фаз знаходиться у дисперсному (роздрібненому) стані. Принциповою особливістю таких систем, зокрема наносистем, $є$ наявність високорозвиненої поверхні поділу фаз. За пропозицією П. О. Ребіндера [6], сучасну колоїдну хімію визна-

(ㄱ Л. Д. Грицан 
чають як “фізико-хімію дисперсних систем і поверхневих явищ”. Саме тому вивчення колоїдної хімії починається з вчення про поверхневі явища, яке являє собою їі теоретичну основу. Така послідовність викладання є логічною, методично виправданою і дозволяє переходити від розгляду загальних співвідношень і закономірностей до конкретних [7-13].

Дисперсні системи широко розповсюджені у фармаціі, до них відноситься більшість лікарських засобів. Для підвищення їх якості та ефективності терапевтичної дії сучасні технології виробництва обов' язково грунтуються на результатах попереднього дослідження сорбційних процесів, змочування, адгезіі. Поверхневі явища також відіграють важливу роль у біохімічних реакціях, у тому числі тих, які перебігають у живих організмах при введенні лікарських речовин.

Відтак вважаю за доцільне зупинитись на деяких методичних підходах до викладання зазначеного змістового модуля.

1. Поверхневі явища обумовлені різним енергетичним станом молекул, які знаходяться у поверхневому шарі, і молекул, розташованих в об' ємі фази. На початку лекції важливо дати визначення понять "поверхневий шар" та "поверхнева енергія Гіббса $G s$ ". При сталих температурі та тиску поверхнева енергія Гіббса визначається добутком поверхневого натягу (фактор інтенсивності) $\sigma$ та площі поверхні поділу фаз (фактор ємності) s

$G^{s}=\sigma s$.

3 рівняння (1) випливає, що система може зменшити свою поверхневу енергію за рахунок самочинного зменшення поверхневого натягу (внаслідок адсорбції, адгезії та змочування, виникнення електричного потенціалу) або зменшення міжфазної поверхні (зміна їі форми та кривини, прояв процесів коагуляції, коалесценціi).

За пропозицією Ю. Г. Фролова [7], класифікацію поверхневих явищ зручно представити у вигляді схеми, складеної для будь-якої гетерогенної системи відповідно до об' єднаного рівняння першого і другого законів термодинаміки:

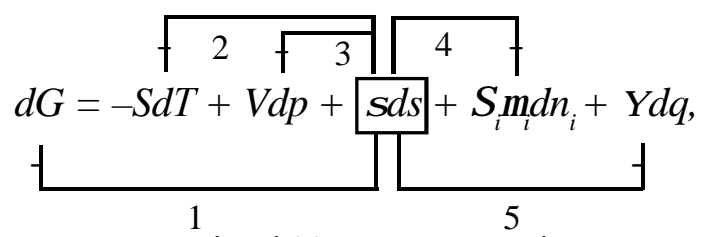

де $G$ - енергія Гіббса; $S$ - ентропія; $T$ - температуpa; $V$ - об'єм; р - тиск; $\sigma$ - поверхневий натяг; s площа поверхні поділу фаз; $\mu_{-}-$хімічний потенціал компонента $\mathrm{i} ; \mathrm{n}_{\mathrm{i}}$ - число молів компонента $i$; $\Psi$ - електричний потенціал; $q$ - кількість електрики.

Рівняння (2) виражає зміну енергії Гіббса системи через суму змін інших видів енергії. Стрілки вказують можливі перетворення поверхневої енергії: 1 -в енергію Гіббса; 2 - в теплоту; 3 - в механічну роботу; 4 - в хімічну енергію; 5 - в електричну енергію. Кожне з цих перетворень відповідає певним процесам на поверхнях поділу фаз, а саме: 1 - зміні реакційної здатності зі зміною дисперсності; 2 - адгезії та змочуванню; 3 - капілярним явищам; 4 - адсорбції; 5 - електрохімічним явищам [13].

Термодинамічний підхід дозволяє викладачу чітко сформулювати визначення кожного 3 поверхневих явищ, допомагає систематизувати великий за обсягом лекційний матеріал. Дуже важливо поєднувати строгість його подання в максимально стислій формі 3 доступністю для розуміння студентами. Тому не варто переобтяжувати зміст лекцій занадто складними математичними виведеннями. 3 метою полегшення його засвоєння студентами на кафедрі фізичної та колоїдної хімії розроблений і постійно вдосконалюється лекційний фонд у мультимедійному форматі. Проведені дослідження свідчать, що впровадження в навчальний процес мультимедійних слайдових презентацій сприяє підвищенню наочності та ефективності представлення лекційного матеріалу, покращує його запам' ятовування студентами $[14,15]$.

2. Фізична та колоїдна хімія є експериментальною дисципліною, тому їі вивчення неможливе без лабораторного практикуму. Знання, які студент одержує з лекцій, підручників та інших методичних джерел, мають бути закріплені під час лабораторних занять. Велика увага повинна приділятись формуванню практичних навичок, які розподілені за темами модуля. Викладач має оцінити рівень підготовки студентів, як $з$ точки зору знання теорії, так і вміння іiі застосовувати при проведенні розрахунків за одержаними експериментальними даними та їх графічним представленням, а також здатності пояснити результати. До навчального посібника [16] включено 7 лабораторних робіт. Вибір їх тем та об'єктів дослідження необхідно проводити залежно від спеціальності в межах відведеної кількості годин.

Вважаю, що студентам, які мають хорошу підготовку 3 хіміі й математики та бажають виконувати індивідуальні експериментальні дослідження, варто надавати таку можливість. Постановка подібних завдань сприяє підвищенню інтересу студентів до навчання. Наприклад, можна запропонувати визначення залежності поверхневого натягу від концен- 
трації водних розчинів кожного з трьох одноатомних спиртів (пропілового, бутилового та амілового). На підставі одержаних експериментальних даних треба побудувати три ізотерми поверхневого натягу $\sigma=$ $\mathrm{f}(\mathrm{c})$, за допомогою яких розрахувати поверхневі активності кожного зі спиртів і, зіставляючи їх значення, проілюструвати правило Дюкло-Траубе.

3. Важливим засобом оволодіння методами фізичної та колоїдної хімії є розв'язування задач. Цей вид навчальної діяльності сприяє розвитку у студентів логічного мислення, а також набуттю навичок практичного застосування теоретичних положень. До глави 8 “Поверхневі явища” збірника задач [17] увійшло 40 задач і вправ різного рівня складності, які можна використовувати як для ілюстрації лекційного матеріалу, так і при проведенні контрольних заходів, а також для організації самостійної роботи студентів. Зазначимо, що профілізовані ситуаційні задачі є найбільш цікавими для студентів. Вони дають їм змогу зрозуміти, для яких цілей можна використати набуті теоретичні знання у майбутній професійній діяльності. Тому ця складова навчального процесу повинна посідати чільне місце. Для ілюстрації наведемо такі приклади.

Приклад 1. Для створення лікарських препаратів пролонгованої дії необхідно дослідження адсорбції на твердих сорбентах. 3 використанням методу IЧспектроскопії було розраховано значення граничної адсорбції $\Gamma_{\propto}$ нітрогліцерину з водно-спиртового розчину на зразках березового активованого вугілля та синтетичного вугілля, які дорівнювали $1,59 \cdot 10^{-4}$ та 3,13 $\cdot 10^{-4}$ моль $\cdot \Gamma^{-1}$ відповідно.

Вважаючи, що адсорбція описується рівнянням Ленгмюра, можна запропонувати студентам на підставі наведених експериментальних даних порівняти величини питомих поверхонь вказаних зразків сорбентів за допомогою рівняння

$s_{\text {пит }}=\Gamma_{\infty} s_{0} N_{A}$,

де $s_{0}$ - площа, яку займає одна молекула адсорбтиву в насиченому адсорбційному моношарі; $N_{A}$ число Авогадро.

3 рівняння (3) випливає, що величина питомої поверхні прямо пропорційна граничній адсорбції, тому відношення питомих поверхонь досліджуваних зразків вугілля дорівнюватиме 1,97. Отже, синтетичне вугілля має більшу площу питомої поверхні.

Обговорюючи результати розрахунків, викладач може підкреслити важливість визначення основної кількісної характеристики сорбентів та каталізаторів

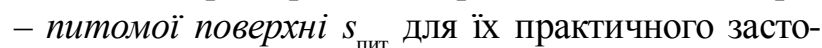
сування. Прийнято два способи їі вираження: як площі поверхні, що припадає на одиницю об' єму сорбенту, $s_{\text {пит }}=s / V$ або як площі поверхні, що припадає на одиницю маси сорбенту $s_{\text {пит }}=s / m$. У першому випадку $s_{\text {пит }}$ виражається в м $^{-1}$. У другому випадку $s_{\text {пит }}$ має розмірність $\mathrm{M}^{2} \cdot \mathrm{\kappa}^{-1}\left(\right.$ або $\left.\mathrm{M}^{2} \cdot \Gamma^{-1}\right)$. У наведених рівняннях $s$, $V$ та $m$ - сумарні площа, об'єм та маса сорбенTy.

Наступна ситуаційна задача знайомить студентів 3 практичним застосуванням гемосорбичї - методу лікування отруєнь та важких захворювань, заснованого на поглинанні із крові токсичних речовин вуглецевими сорбентами [18].

Приклад 2. Перед проведенням процедури гемосорбції активоване вугілля попередньо обробляють альбуміном або іншим білком, котрий, адсорбуючись на поверхні сорбенту, утворює тонку плівку і попереджує руйнування формених елементів крові. Молекулярна маса альбуміну дорівнює 65000 г·моль ${ }^{-1}$; його вміст у плазмі складає $85 \Gamma \cdot{ }^{-1}$. Площа, яку займає молекула альбуміну в насиченому моношарі, дорівнює 60 нм². Макромолекули альбуміну можуть взаємодіяти 3 поверхнею тільки мезо- і макропор активованого вугілля, для яких $s_{\text {пит }}=180 \mathrm{M}^{2} \cdot \Gamma^{-1}$.

На підставі наведених експериментальних даних студентам пропонується із застосуванням положень теорії Ленгмюра обчислити ємність моношару $\Gamma_{\infty}$ i об'єм плазми, необхідний для його створення.

4. Зважаючи на обмежену кількість аудиторних годин, викладач змушений певну частину програмного матеріалу виносити на самостійне опанування студентами. Для організації самостійної роботи студентів на кафедрі фізичної та колоїдної хімї був створений навчально-методичний комплекс, до якого увійшли підручники [9, 10], збірники задач та тестових завдань $[17,19]$, лабораторний практикум [16] та інші матеріали [20]. Велика увага при його розробці була приділена профілізації та адаптації до рівня підготовки студентів 3 хімії, фізики й математики.

Оцінка якості засвоєння окремих тем, які пропонується вивчати самостійно, здійснюється викладачем під час проведення поточних та підсумкових контрольних заходів. Одним із видів самостійної роботи та можливих варіантів їі контролю $є$ виконання розрахунково-графічних завдань, що $є$ особливо корисним для майбутніх інженерів-технологів. Викладач повинен задавати студентам задачі різного рівня складності з урахуванням їх різного рівня підготовки. Розглянемо такий приклад.

Приклад 3. Обчисліть за рівнянням Шишковського $\left(a=17,7 \cdot 10^{-3} ; b=19,72\right)$ поверхневий натяг водних 
розчинів валеріанової кислоти таких концентрацій (моль $\pi^{-1}$ ): 0,005; 0,02; 0,04; 0,10 при 353 К. Поверхневий натяг води при $353 \mathrm{~K}$ становить $62,6 \cdot 10^{-3}$ Дж· $\mathrm{M}^{-2}$. Побудуйте ізотерму поверхневого натягу $\sigma=f(c)$, поясніть іiі хід і зробіть висновок щодо адсорбційної здатності валеріанової кислоти на межі поділу повітря - ії водний розчин.

Як додаткове завдання можна запропонувати студентам розрахувати площу, яку займає молекула валеріанової кислоти на поверхні поділу водний розчин — повітря, а також навести та пояснити схему будови мономолекулярного поверхневого шару за моделлю Ленгмюра.

Спираючись на багаторічний досвід викладання, можна зробити висновок, що виконання подібних завдань допомагає студентам набути навички побудови ізотерм поверхневого натягу і адсорбціі, вміння аналізувати та проводити розрахунки з їх допомогою.

5. Останнім часом відбувається активне впровадження нових освітніх технологій у методи контролю знань студентів [15]. Зокрема, з метою підготовки до складання ліцензійного іспиту “Крок-1” викладачі при проведенні занять навчають студентів розв'язувати типові тестові завдання. До збірника [19] увійшли 89 тестів різного рівня складності за тематикою даного змістового модуля. Приклад такого завдання наведено нижче.

Приклад 4. В результаті експериментального дослідження концентраційної залежності поверхневого натягу на межі поділу повітря - водний розчин валеріанової кислоти були визначені параметри рівняння Шишковського, яке має вигляд:
A.* $\sigma=\sigma_{0}-a \ln (1+b c)$
B. $\sigma=a \ln (1+b c)$
C. $\sigma=\sigma_{0}+a \ln (1+b c)$

\section{Література}

1. Кредитно-модульна система організації навчання у контексті Болонського процесу в Національному фармацевтичному університеті / [В. П. Черних, В. М. Толочко, Л. Г. Кайдалова та ін.]. - Х. : Вид-во НФаУ, 2004. - 68 с.

2. Програма з фізичної та колоїдної хімії для студентів вищих фармацевтичних закладів освіти та фармацевтичних факультетів вищих медичних закладів освіти III-IV рівнів акредитації / [В. І. Кабачний, Л. Д. Грицан, Л. К. Осіпенко та ін.]. -К., 1998. - 24 c.

3. Програма з фізичної та колоїдної хімії для студентів спеціальності 7.110204 “Технологія фармацевтичних препаратів” вищих закладів освіти III-IV рівнів акредитації / В. І. Кабачний, Л. Д. Грицан, Л. К. Осіпенко В. П. Колєснік. - К., 2000. $-28 \mathrm{c}$.
D. $\sigma=\sigma_{0}-a(1+b c)$

E. $\sigma=\sigma_{0}+a(1+b c)$.

Зірочка позначає правильну відповідь.

Висновки: 1. Підвищення рівня підготовки фахівців за напрямами “Фармація” та "Біотехнологія” неможливе без якісного викладання низки фундаментальних дисциплін навчальних планів, до яких відноситься фізична та колоїдна хімія, i, зокрема, іiі розділ “Фізико-хімія поверхневих явищ”.

2. Викладач має постійно працювати над оновленням змісту лекційного курсу 3 метою ознайомлення студентів 3 сучасними науковими й технологічними досягненнями в адаптованому вигляді з урахуванням їх рівня підготовки. Це, безумовно, сприятиме підвищенню інтересу у студентів до подальшого навчання.

3. Сумлінне ставлення до вивчення матеріалу змістового модуля “Фізико-хімія поверхневих явищ” допомагає студенту краще підготуватись до опанування спеціальних і медико-біологічних дисциплін та складання ліцензійного іспиту “Крок-1”. Зокрема, розв’ язання ситуаційних профілізованих задач та розрахунково-графічних завдань, виконання лабораторних робіт активізує навчальний процес і сприяє зміцненню міжпредметних зв' язків. Така організація навчального процесу повною мірою відповідає принципам Болонської системи вищої освіти.

4. В білети для проведення контролю засвоєння даного змістового модуля доцільно включати як тестові завдання, так і ситуаційні задачі, тобто поєднувати нові технології навчання $з$ традиційними.

5. Методика розробки тестових завдань потребує постійної уваги з метою найбільш повного охоплення навчального матеріалу, перевірки вміння студентами аналізувати набуті знання та застосовувати їх на практиці.

4. Кабачний В. І. Програма з фізичної та колоїдної хімії для студентів напряму 6.051401 “Біотехнологія” вищих закладів освіти III-IV рівнів акредитації / В. I. Кабачний, Т. О. Томаровська, Л. Д. Грицан. -К., 2007. - 7 с.

5. Програма з фізичної та колоїдної хімії для студентів вищого фармацевтичного навчального закладу та фармацевтичних факультетів вищих медичних навчальних закладів III-IV рівнів акредитації. Напрям: “Фармація”. Спеціальність: "Технологія парфумерно-косметичних засобів” / В. І. Кабачний, Т. О. Томаровська, Л. Д. Грицан, Л. К. Осіпенко. - К., 2011. -64 с.

6. Ребиндер П. А. Поверхностные явления в дисперсных системах. Коллоидная химия. Избранные труды / П. А. Ребиндер. - М. : Наука, 1978. - 368 с. 
7. Щукин Е. Д. Коллоидная химия / Е. Д. Щукин, А. В. Перцов, Е. А. Амелина. - М. : Высш. шк., 2004. $445 \mathrm{c}$.

8. Фролов Ю. Г. Курс коллоидной химии. Поверхностные явления и дисперсные системы / Ю. Г. Фролов. - М. : Химия, 1988. -464 с.

9. Фізична і колоїдна хімія / [В. І. Кабачний, Л. К. Осіпенко, Л. Д. Грицан та ін.]. - Х. : Прапор, Вид-во НФаУ, 1999. $368 \mathrm{c}$.

10. Физическая и коллоидная химия / [В. И. Кабачный, Л. К. Осипенко, Л. Д. Грицан и др.]. - Харьков : Изд-во НФаУ, 2010. - 432 c.

11. Евстратова К. И. Физическая и коллоидная химия / К. И. Евстратова, Н. А. Купина, Е. Е. Малахова. -М. : Высш. шк., 1990. - 487 с.

12. Біофізична та колоїдна хімія / [А. С. Мороз, Л. П. Яворська, Д. Д. Луцевич та ін.]. - Вінниця : Нова книга, 2007. -600 c.

13. Колоїдна хімія / М. О. Мчедлов-Петросян, В. І. Лебідь, О. М. Глазкова, О. В. Лебідь. - Х. : ХНУ імені В. Н. Каразіна, 2010. -500 c.
14. Особливості застосування мультимедійних презентацій на лекціях у вищому медичному навчальному закладі / І. Р. Мисула, А. А. Гудима, С. І. Шкробот, В. Б. Коваль // Медична освіта. - 2003. - № 2. - С. 10-15.

15. Освітні інновації в Національному фармацевтичному університеті / В. П. Черних, Л. Г. Кайдалова, В. М. Толочко, Т. Ю. Вахрушева. - Х. : Вид-во НФаУ, 2005. - 248 с.

16. Фізична та колоїдна хімія. Лабораторний практикум / [В. І. Кабачний, В. П. Колєснік, Л. Д. Грицан та ін.]. - Х. : Вид-во НФаУ: Золоті сторінки, 2004. - 200 с.

17. Фізична та колоїдна хімія. Збірник задач / [В. І. Кабачний, Л. К. Осіпенко, Л. Д. Грицан та ін.]. - Х. : Вид-воНФаУ; Вид-во ТОВ “Золоті сторінки”, 2001. - 208 с.

18. Николаев В. Г. Гемосорбция на активированных углях / В. Г. Николаев, В. В. Стрелко. - К. : Наукова думка, 1979. $-287 \mathrm{c}$.

19. Сборник тестовых заданий по физической и коллоидной химии / [В. И. Кабачный, Л. Д. Грицан, Л. К. Осипенко и др.]. - Харьков : Изд-во НФаУ, 2007. - 224 с.

20. Грицан Л. Д. Физико-химия поверхностных явлений / Л. Д. Грицан. - Харьков : Изд-во УкрФА, 1994. -73 с. 